UDC 343.93

DOI https://doi.org/10.32840/1813-338X-2019-2-17

\author{
M. M. Koval \\ Candidate of Juridical Sciences, Associate Professor, \\ Associate Professor at the Department of Criminal Law and Processes \\ National University "Lviv Polytechnic"
}

\title{
PSYCHOLOGICAL CHARACTERISTICS OF JUVENILE DELIQUENCY
}

The phenomenon of juvenile delinquency is of great significance for humanity in general and especially for modern Ukrainian society. The process of building the country is accompanied by objective difficulties, crisis phenomena in the economy and other industries, deformations of social consciousness. As a result, the most vulnerable groups of the population are children who are negatively affected. The main cause of juvenile delinquency is improper parenting, lack of parental care for children, material deprivation, negative impact of the environment in the absence of moral barriers. Negative changes in qualitative and quantitative individual and psychological indicators of the identity of juvenile offenders are also important.

Key words: juvenile delinquency, family, "social outsider", personality of juvenile offender.

Formulation of the problem. For domestic legal, social, pedagogical science and practice, "teenage ave" is of great interest. Lawyer once in time faces teenage crime; the teacher is confused about ensuring the minimum assimilation of educational material, the success and discipline of adolescents; social worker throws up his hands: educational neglect of children and adolescents, homelessness, drug addiction, crime is growing. The social situation of development in the teenage period is characterized by the fact that the leading educational activity of the previous period is replaced by activities aimed at determining its own place in the world of adults and in the structure of social relations, on social self-determination. Therefore, this is not a step towards the transformation of a child into an adult, but an independent age-span that has its deep meaning, personal and social significance. The biological significance of the teenage period is defined as a puberty period or period of maturation. Puberty phase is manifested not only in somatic-physiological and neuroendocrine changes, but also in special psychic shifts, which may precede physical maturation and persist for a certain time after its completion. The lower limit of the normal start of physical puberty is 11-12 years old, the upper one is up to 17-18 years old. Traditionally, there are two main phases, called the puberty stage (negative phase) and adolescence (positive phase).

Setting objectives. The purpose of the article is to study the psychological characteristics of juvenile delinquency.
The presentation of main text. The phenomenon of juvenile delinquency is of great importance to humanity as a whole and especially to modern Ukrainian society. The process of building the country is accompanied by objective difficulties, crisis phenomena in the economy and other sectors, deformations of social consciousness. As a result, the most vulnerable groups of the population are children who are negatively affected.

More often, criminal behavior of minors is the result of improper parenting, lack of parental care for children, material deprivation, negative influence of the environment in the absence of moral barriers.

Families and parents often lose their credibility. Parental demands or their anxieties no longer have restraining action. $A$ teenager does not want to be directed, he becomes "deaf to a voice calling for obedience". His behavior begins to be determined by a new attitude: «If parents do not accept me as I am, let them remain without themselves». The interests, values of parents, their installations begin to be taken as anachronistic, only negative is seen everywhere. In this turning point in the relationship, most parents tend to blame children for selfishness. Therefore, with the dominant departure from the family of a teenager may be associated with an acute experience of loneliness, disability in his life.

The underlying global cause of juvenile delinquency is "social outsidering" when children find themselves out of the existing society as a result 
of inadequate socialization. Among other reasons, there is a negative influence of the mass media, an increase in the number of neglected children, shortcomings of the current legislation, instability of social order.

It should be noted that the increase in juvenile delinquency in Ukraine corresponds to the global trend. Thus, over the last five years, the number of crimes committed by minors has increased in the European countries from 40 to $70 \%$, the same figures are observed in the United States, but, as a rule, the number of detected persons who have committed criminal offenses is smaller, which is registered. For example, in 2017, 4298 people aged 14 to 18 were found who committed criminal offenses, and in $2016-4,000$ thousand people of the specified age [1].

The crime of juveniles in most of them acquires the level of the group - about $65 \%$ of crimes are committed by the group. Juveniles easily master new types of crime: kidnapping, extortion, computer crimes, etc. The number of resonant crimes committed by minors, characterized by special cynicism and brutality, is increasing [2, p. 46-49].

The State Institute of Family and Youth issues identifies six main causes of juvenile delinquency: the social and economic aspects of the situation of modern Ukrainian society; functional inadequacy of the family; alienation from the school environment; disadvantages and limited socialization of children in internment facilities; problems in leisure organization; the negative influence of the media. In psychological studies, considerable attention is paid to personality problems, deviant manifestations of behavior.

To date, special attention has to be paid to increasing the number of mentally disabled children $-44 \%$ of juvenile offenders who were registered, various mental abnormalities were observed: oligophrenia, psychosis, psychopathy, neurosis, psychophysical infantilism. In $68 \%$ of special school students for juvenile delinquents neuropsychiatric disorders have been identified: neurotic and neurosis-like manifestations after organic brain damage, mental retardation, patho-haematological changes, psychopathy, enuresis, etc. [1]. These students have violations of carbohydrate and lipid metabolism, reducing the content of some hormones five times compared with healthy children. It is established that such features of metabolism increase the risk of asocial behavior. Children of alcoholic parents are mostly pathologically lagging behind in intel- lectual and physical development; in some cases, in the role of biological causes of social behavior, speech defects, external unattractiveness, flaws of constitutional or somatic character may appear.

The problem of juvenile delinquency with mental anomalies presents a particular danger to social development and requires systematic scientific research and immediate practical legal measures to reduce the number of crimes committed by mentally disabled children.

Also, the criminality of minors is influenced by social factors: negative influence in the family, disadvantages in school education, unemployment socially useful labor, negative impact of the micro-environment, miscalculations in law enforcement agencies in relation to the prevention of juvenile delinquency and other social degradations of society. One of the main factors (up to $90 \%$ ) that pushes minors into a criminal way is a dysfunctional family. Nowadays, an increasing number of families are losing their educational potential due to a number of economic, moral and ethical issues, in connection with which the phenomena of homelessness and neglect are spreading, which leads to an increase in juvenile delinquency [3, p. 129].

Also, one of the important factors that indirectly determines the juvenile delinquency is the miscalculation of law enforcement activities. Often, they are limited only to a superficial study of statistics without careful study of the causes and conditions conducive to juvenile delinquency. State programs aimed at preventing juvenile delinquency are not sufficiently funded, therefore, they do not play a role..

Also, it should be noted the role of alcohol and other intoxicating substances in shaping the personality of a juvenile offender, removing the psychological barriers to the infringing conduct. The rate of drug addiction in juveniles is 2.5-3 times higher than in adults. It should be noted that juveniles are not only personally consuming stuffing substances, but also take an ever more active part in criminal activities associated with drug trafficking [4, p. 417-424].

Negative changes in qualitative and quantitative individual and psychological indicators of the identity of juvenile offenders are also important.

In juvenile offenders as opposed to law-abiding peers, stheniac options interpersonal communication are dominated. Convicts admit that they have such features of character as dominance, leadership, independence, straightforwardness, aggres- 
siveness. Thus, the killers are characterized by a high level of physical aggression, thieves - indirect aggression, hooligans-indolence and verbal aggression, rape - suspicion. The presence of the above-mentioned features of nature dramatically reduces the level of their law-making adaptation. Juvenile offenders have an increase in mental fatigue (2 times compared with normal children), anxiety (1.5 times) with simultaneous decrease in work capacity, self-regulation level ( 3 times), adaptation coefficient (2 times) [5, ch. 17].

Emotional-volitional sphere of juvenile offenders is characterized by imbalance, impulsiveness, stubbornness, insufficient level of self-control, self-discipline, poverty of emotional manifestations, incommensurability of subtle feelings. Some part of juvenile offenders is characterized by the failure of the system of ethical beliefs and universal values. Primitive physiological needs in food, sexual intercourse, etc. are the motivation for their criminal behavior. Among the characteristic features should be noted the reluctance to perform some kind of activity, rudeness, self-centeredness, falsehood, infantilism, low anti-smoking ability to reduce the criticality to their own behavior.

The intellectual sphere is characterized by low indicators of intelligence, a narrow mindset, a lack of vocabulary, a low development of abstract thinking and, consequently, the inability to predict the results of their own activities. However, the comprehensive study of the phenomenon of juvenile delinquency with the analysis of the determinants causing it and the psychological characteristics of juvenile offenders in the available literature is not sufficiently covered. Therefore, the definition of various psychological aspects of the development of juvenile delinquency from the point of view of the systemic approach becomes of particular importance..

According to Art. 60 Part 1 Art. 62 of the Constitution of Ukraine and Part 1 of Art. 11 of the Criminal Code of Ukraine in criminal law only liability is possible. Ukraine's criminal law does not know liability without fault. Without guilt there is no crime. Characteristics of the personality of a juvenile offender are necessary for the disclosure of crimes committed by them, since it involves obtaining forensically meaningful information about it, which includes information about the inherent anatomical, biological, psychological and social properties that are necessary for identification of a person, solving tactical tasks and setting the actual picture of the crime event in the process of its disclosure and investigation. Investigation of the personality of the offender from forensic positions is aimed at obtaining data on the person, such as characterizing its social nature, criminal professionalism, and other data that may contribute to the search and establishment of the suspect, to predict possible investigatory situations of the investigation and to identify measures for their resolution. [6, p. 74].

A detailed and comprehensive study of the individual young person contributes to the individualization of punishment. Relationship of the data structure of a private minor with the degree of social danger of a crime committed by him, although he has an indirect character, but their identification and consideration are essential for achieving the goal of education and moral restoration of the adolescent's personality [7, p. 11].

Penalty as a mandatory sign of a crime means that sanctions of a special part of the Criminal Code of Ukraine provide for punishment for each crime. As V.P. Tykhyi and M.I. Panov, punishment is the reverse side of crime, legislative (criminal) threat of punishment for committing a crime [8, p. 11] Penalty as a mandatory sign of a crime means that punishment as a sign of a crime does not mean that every crime entails a real use and punishment. Criminal law provides for the allocation of juvenile offenses cases exemption from criminal liability, from punishment and his serving a special part of the Criminal Code of Ukraine for each crime is punishable. As V.P. Quiet and MI Panov, punishment-the reverse side of crime, legislative (criminal law) threat of punishment for the commission of a crime $<\ldots>$. Art. 44-49 of Criminal Code of Ukraine provide legal grounds and the procedure for exemption from criminal liability, and Art. 74-87 of Criminal Code of Ukraine establish the grounds and order of release from punishment and his serving. The criminal legislation of Ukraine establishes the features of criminal liability and punishment of minors, in particular, Art. 97 of the Criminal Code of Ukraine contains provisions on the release of juveniles from criminal responsibility with the use of coercive measures. Minors were found guilty of committing a crime, may be punished by the court - a fine, social work, arrest, deprivation of liberty for a certain period. The list of these punishments is exhaustive and nobody can expand or modify it.

Conclusions. Having considered the question of the characterization of a juvenile offender, we can conclude that this topic is very relevant and widespread. We believe that the main causes 
of juvenile delinquency are social and property inequities, which causes envy and anger that provokes the commission of crimes against property; uncontrolled parents influence of social networks and other Internet resources; domestic violence, other family circumstances. Parents should educate their children and be an example and explain how to deal with different difficult situations, children have to trust their parents and not be afraid to share their problems.

\section{References:}

1. Statystychna informatsiia. Pro zareiestrovani kryminalni pravoporushennia ta rezultaty yikh dosudovoho rozsliduvannia. URL: https:// www.gp.gov.ua/ua/stst2011.html?dir_id=113653\& libid $=100820 \& c=$ edit\& $c=$ fo

2. Harkavets S.O. Problema deviatsii u povedintsi studentskoi molodi. Aktualni problemy psykholohii : Zb. nauk. prats In-tu psykholohii im. H.S. Kostiuka APN Ukrainy. 2007. T. 7, vyp. 12 «Ekolohichna psykholohiia». P. 46-49.
3. Problemy bezdohliadnosti ta bezprytulnosti ditei v Ukraini : tematychna derzhavna dopovid pro stanovyshche ditei Ukrainy za pidsumkamy 2006 roku. Kiev : Derzh. in-t problem simi ta molodi, 2007. $240 \mathrm{p}$.

4. Riepina O.H., Arshava I.O., Aminieva Ya.R. Osoblyvosti psykholohichnoho zdorovia nepovnolitnikh zlochyntsiv. Zb. nauk. prats «Pedahohika vyshchoi ta serednoi shkoly». Kryvyi Rih : SPD Shcherbaniuk, 2010. P. 417-424.

5. Harkavets S.O. Psykholohichni osoblyvosti systemy tsinnostei pravoporushnyka : Avtoref. dys. ... kand. psykhol. nauk. Kharkiv, 2001. 17 p.

6. Holina V.V. Kryminolohichna kharakterystyka i poperedzhennia zlochynnosti nepovnolitnikh. Pytannia borotby zi zlochynnistiu : Zb. nauk. pr. Kharkiv : Pravo, 2004.V. 8. P. 74.

7. Bandurka I.O. Kryminolohichna kharakterystyka osobystosti nepovnolitnoho zlochyntsia. Nashe pravo. № 6. 2014. P. 92-100.

8. Tykhyi V.P., Panov M.I., Zlochyn, yoho vydy ta stadii. Naukovo-praktychnyi komentar. Kyiv : vyd. Dim «Promin». 2007. P. 11.

\section{Коваль М. М. Психологічна характеристика злочинності неповнолітніх}

Феномен злочинності неповнолітніх має велике значення для людства у цілому та особливо для сучасного українського суспільства. Прочес розбудови країни супроводжується об'єктивними труднощами, кризовими явищами в економіці та інших галузях, дефрормаціями суспільної свідомості. Як наслідок, негативному впливу піддаються найменш захищені верстви населення - діти. Головною причиною злочинності неповнолітніх $є$ неправильне виховання, відсутності догляду батьків за дітьми, матеріальних нестатків, негативного впливу оточення за відсутності моральних бар'єрів. Важливими є також негативні зміни у якісних та кількісних індивідуально-психологічних показниках особистості неповнолітніх злочинців.

Ключові слова: злочинність неповнолітніх, сім'я, «соціальне аутсайдерство», особистість неповнолітнього злочинця.

Коваль М. М. Психологическая характеристика преступности несовершеннолетних

Феномен преступности несовершеннолетних имеет большое значение для человечества в целом и особенно для современного украинского общества. Процесс развития страны сопровождается объективными трудностями, кризисными явлениями в экономике и других областях, дефоормациями общественного сознания. Как следствие, негативное влияние подвергаются наименее защищенные слои населения - дети. Главной причиной преступности несовершеннолетних является неправильное воспитание, отсутствие ухода родителей за детьми, материальных лишений, негативного влияния окружения при отсутствии моральных барьеров. Важны также негативные изменения в качественных и количественных индивидуально-психологических показателях личности несовершеннолетних преступников.

Ключевые слова: преступность несовершеннолетних, семья, «социальное аутсайдерство», личность несовершеннолетнего преступника. 